\title{
PENGEMBANGAN MODEL PEMBELAJARAN BLENDED LEARNING PADA MATA PELAJARAN EKONOMI KD SISTEM DAN ALAT PEMBAYARAN KELAS $X$ IPS DI SMAN 2 JEMBER TAHUN PELAJARAN 2016/2017
}

\author{
Mayya Muwallidah ${ }^{1}$, Retna Ngesti Sedyati ${ }^{1}$, Hety Mustika Ani ${ }^{1}$ \\ ${ }^{1}$ Program Studi Pendidikan, Fakultas Keguruan dan Ilmu Pendidikan, Universitas Jember \\ e-mail: retnasedyati.fkip@unej.ac.id
}

\begin{abstract}
Abstrak
Penelitian ini bertujuan untuk mengembangkan model pembelajaran blended learning. Penelitian ini bertujuan untuk: (1) model pembelajaran blended learning pada KD sistem dan alat pembayaran (2) mengetahui tingkat kemenarikan, efektivitas dan efisiensi model pembelajaran blended learning pada KD sistem dan alat pembayaran. Jenis penelitian adalah penelitian dan pengembangan dengan menggunakan model penelitian dan pengembangan ADDIE tahap-tahap: (1) analisis; (2) desain; (3) pengembangan ; (4) implementasi; dan (5) evaluasi. Subjek uji coba penelitian ini berjumlah 35 peserta didik kelas X IPS 2 SMA Negeri 2 Jember. Teknik pengumpulan data menggunakan lembar validasi, angket respon peserta didik, pedoman wawancara, tes hasil belajar, dan metode dokumen. Teknik analisis data yang digunakan adalah analisis uji kemenarikan dengan angket respon peserta didik, uji efektivitas model dengan tes menggunakan SPSS v22 untuk melihat perbedaan perbedaan hasil belajar dan efisiensi model dengan wawancara kepada guru dan perbedaan waktu di silabus. Hasil penelitian menunjukkan bahwa: (1) model pembelajaran blended learning ini berhasil dikembangkan melalui beberapa tahapan, yaitu analisis, desain, pengembangan, implementasi, dan evaluasi; (2) hasil penilaian ahli materi mendapatkan rata-rata tahap I 71,88\%, tahap II 93,75\% dan tahap III 100\% dengan kategori "baik sekali”; hasil penilaian ahli model blended learning mendapatkan rata-rata tahap I 58,33\% tahap II 95,83\%, tahap III 100\% dengan kategori "baik sekali"; dan hasil uji coba pengguna mendapatkan rata-rata $86 \%$ dengan kategori "sangat menarik". Efektivitas model blended learning dilihat dari peningkatan rata-rata hasil belajar peserta didik sebesar 80. Pengukuran efisiensi model blended learning terhadap target waktu berkurang menjadi 9x45 menit atau 3x pertemuan dari yang disediakan disilabus 12x45 menit atau 4x pertemuan. berdasarkan hasil yang diperoleh tersebut menunjukkan, model blended learning lebih menarik, lebih efektif dan lebih efisien terhadap model sebelumnya (klasikal) di kelas X IPS 2 di SMA Negeri 2 Jember pada KD sistem dan alat pembayaran.
\end{abstract}

Kata Kunci: Pengembangan, model blended learnings

\section{PENDAHULUAN}

Tujuan utama dari pendidikan adalah untuk mencerdaskan kehidupan bangsa, serta mengamanatkan kepada pemerintah agar mengusahakan dan menyelenggarakan satu sistem pendidikan nasional. Oleh karena itu pemerintah menerapkan kurikulum yang berlaku untuk sekolah di Indonesia. Kurikulum yang terbaru adalah kurikulum 2013.

Kurikulum sebelumnya yang diterapkan di Indonesia adalah kurikulum tingkat satuan pendidikan (KTSP), kedudukan guru yang pada awalnya sebagai sumber belajar, pada kurikulum 2013 guru berkedudukan sebagai agen pembelajar, terkait dengan peran guru sebagai agen pembelajar, guru dituntut dapat memberikan pembelajaran secara optimal dengan menggunakan berbagi macam metode dan model pembelajaan yang disesuaikan dengan karakteristik peserta didik, karena Pemilihan dan penerapan desain model pembelajaran menjadi salah satu faktor penentu keberhasilan penguasaan kompetensi peserta didik.

Menurut (Aunurrohman, 2013:146) Model pembelajaran dapat diartikan sebagai kerangka konseptual yang melukiskan prosedur yang sistematis dalam mengorganisasikan pengalaman belajar untuk mencapai tujuan belajar tertentu, dan berfungsi sebagai pedoman bagi para perancang pembelajaran dan para guru untuk merencanakan dan melaksanakan aktivitas pembelajaran. 
Sekolah SMAN 2 Jember menggunakan model pembelajaran klasikal. Namun penggunaan model klasikal belum menarik perhatian peserta didik karena guru hanya berceramah menggunakan power point yang ditampilkan di depan kelas dan peserta didik hanya mencatat isi power point tersebut. Model pembelajaran yang kurang menarik menyebabkan peserta didik kesulitan dalam memahami materi sehingga berdampak pada hasil belajar peserta didik yang kurang memuaskan, selain itu guru harus mengulang kembali materi yang sama untuk mendapatkan hasil belajar peserta didik yang memuaskan. Oleh karena itu di butuhkan model pembelajaran yang menarik, efektif dan efisien.

Model pembelajaran dikatakan menarik jika model tersebut bisa menumbuhkan motivasi dan semangat belajar bagi peserta didik, menurut Aunurrahman (2014:141) pengembangan model pembelajaran dimaksudkan untuk menumbuhkan dan meningkatkan motivasi belajar peserta didik agar mereka tidak jenuh dengan proses belajar yang sedang berlangsung.

Penggunaan model pembelajaran dapat membantu guru untuk mencapai tujuan pembelajaran karena akan berpengaruh terhadap respon peserta didik selama pelajaran berlangsung, untuk itu guru harus mengetahui model pembelajaran yang baik dan sesuai dengan karakteristik peserta didik. Menurut Aunurrahman (2014:143) bahwa penggunaan model pembelajaran yang tepat dapat mendorong tumbuhnya rasa senang peserta didik terhadap pembelajaran, menumbuhkan dan meningkatkan motivasi dalam mengerjakan tugas, memberikan kemudahan bagi peserta didik untuk memahami pelajaran sehingga memungkinkan peserta didik mencapai hasil belajar yang lebih baik.

Efisiensi adalah kemampuan untuk menggunakan waktu dengan baik dan tepat. Efisiensi model pembelajaran pada penelitian pengembangan ini dapat dilihat melalui penggunaan waktu pertemuan yang dibutuhkan dalam penyampaian materi. Menurut Rohani (2010:33) pengajaran yang baik adalah apabila proses pengajaran itu menggunakan waktu yang cukup (efisien).

Model Blended learning adalah belajar yang mengkombinasi antara pembelajaran tatap muka dan pembelajaran berbasis komputer (online dan offline). Menurut Dwiyogo, 2011 (dalam Husamah, 2014:12) blended learning adalah pembelajaran kombinasi antara tatap muka, pembelajaran berbasis komputer (offline), dan pembelajaran berbasis internet (online).

Berdasarkan hal yang dipaparkan diatas, peneliti tertarik untuk melakukan penelitian pengembangan dengan judul "Pengembangan Model Blended Learning pada Mata Pelajaran Ekonomi Kelas X IPS KD Alat dan Sistem Pembayaran SMAN 2 Jember Tahun Pelajaran 2016/2017"

\section{METODE}

Penelitian pengembangan ini menggunakan model penelitian pengembangan ADDIE yaitu penelitian yang digunakan untuk menghasilkan produk tertentu, dan menguji keefektifan produk tersebut.

Adapun tahapan dari model ADDIE ada 5 yakni sebagai berikut (Tegeh, 2014:42-44)

1. Tahap 1 analisis (Analyze)

Tahap anlisis (Analyze) meliputi kegiatan sebagai berikut: (a) melakukan analisis kompetensi yang dituntut kepada peserta didik. Pada tahap anlisis kompetensi, menganalisis kemampuan yang harus dimiliki oleh peserta didik, tujuan pembelajaran yang harus di capai oleh peserta didik, model pembelajaran yang selama ini digunakan oleh guru dan hasil belajar yang diperoleh peserta didik (b) melakukan analisis karakteristik peserta didik tentang kapasitas belajarnya, pengetahuan keterampilan, sikap yang telah dimiliki peserta didik serta aspek lain yang terkait. Telaah tentang karakteristik peserta didik sesuai dengan rancangan dan pengembangan model pembelajaran. Untuk mengetahui karakteristik peserta didik kelas X IPS 2 SMAN 2 Jember melalui diskusi dengan guru mata pelajaran ekonomi, karakteristik ini meliputi latar belakang pengetahuan, kemampuan akademik, perkembangan kognitif siswa dan 
kemampuan peserta didik pada bidang teknologi. (c) melakukan analisis materi sesuai dengan tututan kompetensi. Menganalisis terkait materi-materi yang akan disampaikan pada kd sistem dan alat pembayaran sesuai dengan kurikulum dan silabus yang digunakan di SMAN 2 Jember.

2. Tahap 2 Perancangan (Design)

Tahap perancangan (Design) hal-hal yang dilakukan merancang pembelajaran difokuskan pada tiga kegiatan, yaitu pemilihan materi sesuai dengan karakteristik peserta didik dan tutunan kompetensi, strategi pembelajaran yang diterapkan dan bentuk serta model assesmen dan evaluasi yang digunakan. a). Mendesain model pembelajaran berdasarkan karakteristik peserta didik sesuai hasil dari analisis yang dilakukan di awal. b). Mendesain RPP (rencana pelaksanaan pembelajaran) dan media pembelajaran untuk mendukung proses pembelajaran peserta didik. c). Mendesain assesmen dan evaluasi berdasarkan karakteristik peserta didik.

3. Tahap 3 Pengembangan (Development)

Tahap pengembangan (Development) yang pada intinya adalah kegiatann menerjemahkan spesifikasi desain ke dalam bentuk fisik, sehinga kegiatan ini menghasilkan prototype produk pengembangan. Segala hal yang telah dilakukan pada tahap perancangan, yakni pemilihan materi sesuai dengan karakterisktik peserta didik dan tuntutan kompetensi, strategi pembelajaran yang diterapkan dan bentuk serta metode asesmen dan evaluasi yang digunakan diwujudkan dalam bentuk prototype. Kegiatan tahap pengembangan antara lain: a) Mengembangkan desain model pembelajaran atau prototype untuk divalidasi oleh evaluator. b) Melakukan revisi desain model pembelajaran, jika ada tambahan dan usulan dari evaluator. c) Melakukan validasi kembali setelah direvisi sampai dinyatakan layak oleh validator untuk diimplementasikan.

4. Tahap 4 Implementasi (Implementation)

Tahap implementasi (Implementation), hasil pengembangan diterapkan keefektifan, kemenarikan dan efisiensi pembelajaran. Prototype produk pengembangan perlu diuji cobakan secara rill dilapangan untuk memperoleh gambaran tentang tingkat efektifan, kemenarikan dan efisiensi pembelajaran. a) Tahap implementasi dilakukan dua kali uji coba yakni uji coba terbatas dan uji coba luas. b) Uji coba terbatas dilakukan untuk menilai apakah produk layak untuk diuji coba luaskan dengan mengambil sampel dari subjek ujicoba luas. c) Uji coba luas dilakukan untuk mengimplementasikan produk secara penuh kepada subjek uji coba yakni kelas X IPS 2 SMAN 2 Jember.

5. Tahap 5 Evaluasi (Evaluation)

Tahap evaluasi (Evaluation) yang meliputi evaluasi formatif dan evaluasi sumatif. Evaluasi formatif dilakukan untuk mengumpulkan data pada setiap tahapan yang digunakan untuk penyempurnaan dan evaluasi sumatif dilakukan pada akhir program untuk mengetahui pengaruhnya terhdap hasil belajar peserta didik dan kualitas pembelajaran secara luas. Dalam penelitian pengembangan umumnya hanya dilakukan evaluasi formatif, karena jenis evaluasi ini berhubungan dengan tahapan penelitian pengembagan untuk memperbaiki produk pengembangan yang dihasilkan. a) Tahap evaluasi dilakukan evaluasi formatif yang bersifat kotinu, evaluasi dilakukan pada setiap tahap mulai dari desain sampai dengan tahap implementasi. b) Tahap evaluasi dilakukan oleh evaluator pada saat tahap pengembangan produk. c) Evaluasi dilakukan oleh peneleti pada saat selesai melakukan uji coba jika dirasa perlu.

Penelitian ini menggunakan subjek uji coba peserta didik kelas X IPS 2 SMA Negeri 2 Jember. Subjek uji coba terbatas berjumlah 12 peserta didik dipilih secara heterogen sesuai dengan kemampuan peserta didik dan uji coba luas berjumlah 35 peserta didik. tahapan-tahapan penelitian dan 
pengembangan ditunjukkan pada gambar dibawah ini:

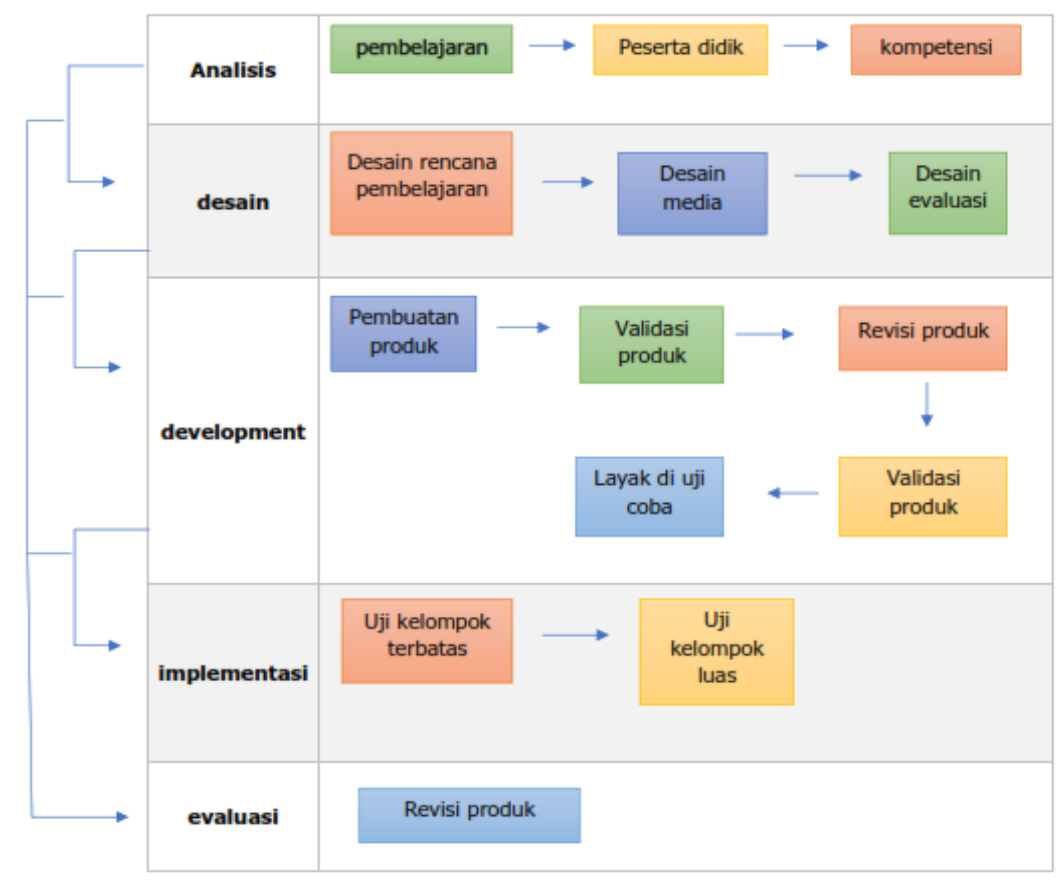

Gambar 1. Prosedur Pengembangan ADDIE

\section{HASIL DAN PEMBAHASAN}

\section{Hasil Penelitian}

\section{Validasi Ahli Materi Dan Model}

Uji kelayakan model pembelajaraan blended leaning dilakukan uji validasi oleh validator isi/materi dan model. Validator isi/materi dan model dipilih untuk melkaukan validasi dan penilaian terhadap model yang dikembangkan. Validasi dilakukan dengan menggunakan instrumen penlilaian ahli materi dan model dengan 3 tahap.

Validator isi adalah guru pengampu mata pelajaran ekonomi kelas $\mathrm{X}$, validasi ini dilakukan untuk melihat apakah produk yang akan dikembangkan sudah layak untuk di terapkan. Pada validasi tahap I skor yang diperoleh adalah 71,88\% sehingga dikategorikan perlu direvisi kembali, Pada validasi tahap II skor yang diperoleh mengalami peningkatan menjadi $93,75 \%$ sehingga dikategorikan layak tetapi ada yang harus direvisi kembali, Pada validasi tahap III skor yang diperoleh adalah 100,00\% sehingga dikategorikan layak untuk ditrapkan dan tidak perlu direvisi kembali.

Validator model adalah dosen pendidikan ekonomi FKIP universitas Jember, validasi ini dilakukan untuk melihat apakah produk yang akan dikembangkan sudah layak untuk di terapkan. Pada validasi tahap I skor yang diperoleh adalah 58,33\% sehingga dikategorikan perlu direvisi kembali, Pada validasi tahap II skor yang diperoleh adalah 95,83\% sehingga dikategorikan layak tetapi ada yang harus direvisi kembali, Pada validasi tahap III skor yang diperoleh adalah 100,00\% sehingga dikategorikan layak untuk ditrapkan dan tidak perlu direvisi kembali.

\section{Hasil Uji Coba Terbatas}

1. Kemenarikan model blended learning

Berdasarkan hasil rekapitulasi rata-rata respon kemenarikan model blended learning bagi peserta didik, yang diperoleh dari angket kemenarikan diketahui pada tahap uji coba kelompok terbatas, peserta didik memberikan respon dengan jumlah rata-rata skor $83,56 \%$ yang diperoleh 
dari angket yang sudah didistribusikan ke 12 peserta didik sehingga dapat dikategorikan menarik sekali dalam uji coba terbatas dan dapat dilanjutkan dengan uji coba luas.

2. Efektivitas model blended learning

Hasil uji beda paired sample $t$ test dengan bantuan sofware SPSS versi 22, diketahui tingkat efektivitas model blended learning ditunjukkan pada tabel di bawah ini

Tabel: Hasil Statistik dengan Sampel Berpasangan pada Uji Coba Terbatas

\begin{tabular}{|l|l|r|r|r|r|}
\hline \multicolumn{7}{|c|}{ Paired Samples Statistics } \\
\hline \multirow{2}{*}{} & \multicolumn{1}{|c|}{ Mean } & \multicolumn{1}{|c|}{ N } & Std. Deviation & \multicolumn{2}{c|}{$\begin{array}{c}\text { Std. Error } \\
\text { Mean }\end{array}$} \\
\hline Pair 1 & PRETEST & 70,50 & 12 & 8,051 & 2,324 \\
\cline { 2 - 7 } & POSTEST & 79,83 & 12 & 2,758 &, 796 \\
\hline & & & & & \\
\hline
\end{tabular}

Berdasarkan tabel diatas diketahui bahwa rata-rata dari nilai peserta didik pada saat pretest adalah 70,50 sedangkan pada saat postest rata-rata dari nilai peserta didik adalah 79,83 , hal ini menunjukkan peningkatan hasil belajar peserta didik sebelum dan sesudah menggunakan model blended learning, karena adanya peningkatan hasil belajar menunjukkan bahwa model blended learning efektif.

3. Efisiensi model blended learning

Pengukuran efisiensi dilakukan dengan perbandingan waktu yang digunakan dalam pembelajaran ekonomi KD Sistem dan alat pembayaran. berdasarkan hasil yang diperoleh dari wawancara dengan guru mata pelajaran ekonomi jumlah waktu yang digunakan lebih sedikit dari waktu yang telah ditentukan disilabus, target waktu yang ditentukan disilabus adalah $12 \times 45$ menit atau $4 \mathrm{x}$ pertemuan, dengan menggunakan model pembelajaran blended learning dapat mempersingkat waktu pembelajaran menjadi 9x45 menit atau 3x pertemuan, sisa waktu yang tersedia $3 \times 45$ menit atau $1 \mathrm{x}$ pertemuan digunakan guru untuk pengayaan.

\section{Hasil Uji Coba Luas}

1. Kemenarikan model blended learning

Kemenarikan model blended learning didapatkan dari angket yang didistribusikan kepada peserta didik setelah uji coba luas, dari uji coba terbatas ini didapatkan hasil respon peserta didik pada model blended learning. Berdasarkan hasil rekapitulasi rata-rata respon kemenarikan model blended learning bagi peserta didik, yang diperoleh dari angket kemenarikan diketahui pada tahap uji coba kelompok terbatas, peserta didik memberikan respon dengan jumlah rata-rata skor $86,43 \%$ yang diperoleh dari angket yang sudah didistribusikan ke 35 peserta didik sehingga dapat dikategorikan menarik sekali.

\section{Efektivitas model blended learning}

Hasil uji beda paired sample t test dengan bantuan sofware SPSS versi 22, diketahui tingkat efektivitas model blended learning ditunjukkan pada tabel di bawah ini

Tabel: Hasil Statistik dengan Sampel Berpasangan pada Uji Coba Luas

\begin{tabular}{|l|l|r|r|r|r|}
\hline \multicolumn{7}{|c|}{ Paired Samples Statistics } \\
\hline \multicolumn{2}{|c|}{} & \multicolumn{1}{|c|}{ Mean } & N & Std. Deviation & \multicolumn{1}{c|}{ Std. Error Mean } \\
\hline Pair 1 & PRETEST & 72,51 & 35 & 8,194 & 1,385 \\
\cline { 2 - 6 } & POSTEST & 80,23 & 35 & 3,993 &, 675 \\
\hline
\end{tabular}


Berdasarkan tabel diatas diketahui bahwa rata-rata dari nilai peserta didik pada saat pretest adalah 72,51 sedangkan pada saat postest rata-rata dari nilai peserta didik adalah 80,23 , hal ini menunjukkan peningkatan hasil belajar peserta didik sebelum dan sesudah menggunakan model blended learning, karena adanya peningkatan hasil belajar menunjukkan bahwa model blended learning efektif.

\section{Efisiensi model blended learning}

Pengukuran efisiensi dilakukan dengan perbandingan waktu yang digunakan dalam pembelajaran ekonomi KD Sistem dan alat pembayaran. berdasarkan hasil yang diperoleh dari wawancara dengan guru mata pelajaran ekonomi jumlah waktu yang digunakan lebih sedikit dari waktu yang telah ditentukan disilabus, target waktu yang ditentukan disilabus adalah $12 \times 45$ menit atau $4 \mathrm{x}$ pertemuan, dengan menggunakan model pembelajaran blended learning dapat mempersingkat waktu pembelajaran menjadi 9x45 menit atau 3x pertemuan, sisa waktu yang tersedia $3 \times 45$ menit atau $1 \mathrm{x}$ pertemuan digunakan guru untuk pengayaan.

\section{Pembahasan}

Pembahasan pada penelitian ini bertujuan untuk menjelaskan hasil penelitian pengembangan model pembelajaran blended learning pada KD sistem dan alat pembayaran untuk peserta didik kelas $\mathrm{X}$ IPS di SMAN 2 Jember, yang ditinjau dari tingkat kemenarikan, efektivitas dan efisiensi model pembelajaran. Hasil penelitian pengembangan yang telah dilakukan menghasilkan model pembelajaran yang lebih menarik, lebih efektif dan lebih efisien dari model sebelumnya yang digunakan (klasikal). Peneliti melakukan model prosedural yang di adaptasi dari Robert Maribe Branch dengan pendekatan ADDIE. Prosedur tersebut terdiri dari lima tahap, yaitu analisis, desain, development, implementation dan evaluation.

Kemenarikan model pembelajaran blended learning dapat dilihat dari angket respon yang telah diberikan kepada peserta didik pada saat uji coba produk. Hasil yang diperoleh dari angket tersebut diketahui bahwa model pembelajaran blended learning mendapat respon positif dari sebagaian besar peserta didik di kelas X IPS 2. Hasil dari angket sebagaian besar peserta didik termotivasi dalam pembelajaran pada saat pembelajaran menggunakan model blended learning. hal ini sesuai dengan pendapat Aunurrahman (2014:141) pengembangan model pembelajaran dimaksudkan untuk menumbuhkan dan meningkatkan motivasi belajar peserta didik agar mereka tidak jenuh dengan proses belajar yang sedang berlangsung. Selain itu juga didukung oleh pernyataan dari salah satu peserta didik yaitu sebagai berikut.

"Saya senang pembelajaran menggunakan model ini, karena tidak hanya diterangkan tapi juga ada video, dan juga saya tidak perlu mencatat banyak-banyak dibuku karena sudah ada onlinenya jadi saya bisa belajar lewat online, dan juga saya bisa mengerjakan latihan-latihan dan tugas kapan saja" (F, 16 Tahun)

Ditinjau dari tingkat efektivitas, model blended learning merupakan model pembelajaran yang efektif digunakan dalam proses pembelajaran ekonomi di kelas X IPS 2 SMAN 2 Jember yang ditunjukkan dengan semakin meningkatnya rata-rata hasil belajarnya yang diperoleh dibanding dengan sebelum menggunakan media yang dikembangkan serta dihitung didukung dengan hasil perhitungan uji beda (paired sample t test).

Pada saat uji coba lebih luas nilai rata-rata peserta didik sebelum menggunakan model blended learning adalah 72,51. Sedangkan, sesudah diberikan penjelasan materi dengan menggunakan model blended learning nilai rata-rata peserta didik adalah 80,23. Hal ini menunjukkan bahwa terdapat peningkatan hasil belajar yang diperoleh peserta didik. Perbedaan yang nyata antara hasil belajar peserta 
didik sebelum menggunakan model blended learning dan hasil belajar peserta didik setelah menggunakan model blended learning, menunjukkan bahwa model blended learning pada mata pelajaran ekonomi KD sistem dan alat pembayaran efektif untuk mencapai tujuan pembelajaran. Sehingga dapat disimpulkan model pembelajaran blended learning lebih efektif untuk meningkatkan hasil belajar peserta didik.

Hal ini sesuai dengan pendapat (Aunurrahman, 2014:143) bahwa penggunaan model pembelajaran yang tepat dapat mendorong tumbuhnya rasa senang peserta didik terhadap pembelajaran, menumbuhkan dan meningkatkan motivasi dalam mengerjakan tugas, memberikan kemudahan bagai peserta didik untuk memahami pelajaran sehingga memungkinkan peserta didik mencapai hasil belajar yang lebih baik.

Efisiensi model pembelajaran blended learning dilihat dari penggunaan waktu yang menjadi lebih cepat menyampaikan materi-materi pada KD sistem dan alat pembayaran. Hasil pada saat uji coba luas proses pembelajaran ekonomi pada KD sistem dan alat pembayaran berkurang menjadi 9x45 menit atau $3 \mathrm{x}$ pertemuan dari waktu yang telah ditentukan di silabus yakni $12 \times 45$ menit atau $4 \mathrm{x}$ pertemuan. Sesuai dengan pendapat dari Rohani (2010:33) bahwa pembelajaran yang baik adalah proses pembelajaran yang menggunakan waktu yang cukup (efisien). Berdasarkan uji coba luas dapat diketahui tingkat efisiensi model pembelajaran blended learning ini mempersingkat waktu pembelajaran dan pemahaman peserta didik terhadap materi. Hal ini didukung dengan hasil wawancara terhadap guru mata pelajaran ekonomi sebagai berikut.

"Model pembelajaran blended learning ini bagus, saya bisa mempersingkat waktu pembelajaran, yang biasanya saya harus menjelaskan semua, sekarang ada video dan peserta didik dapat memperhatikan dengan baik, dan mereka juga membaca materi dan latihan soal dengan antusias di quipper school" (DY,48 tahun)

Selain itu, tingkat efisiensi model pembelajaran blended learning juga terlihat pada berkurangnya waktu dalam kegiatan proses pembelajaran. Bahwa waktu yang digunakan dalam setiap kegiatan proses pembelajaran lebih singkat dibandingkan dengan proses pembelajaran yang menggunakan model klasikal.

Berdasarkan pembahasan yang telah dijelaskan di atas menunjukkan bahwa model pembelajaraan blended learning lebih menarik, lebih efektif dan lebih efisien terhadap model pembelajaran sebelumnya (klasikal) dalam mencapai tujuan pembelajaran peserta didik kelas X IPS 2 di SMAN 2 Jember pada KD sistem dan alat pembayaran.

\section{PENUTUP}

Berdasarkan hasil penelitian pengembangan model blended learning pada KD sistem dan alat pembayaran kelas X IPS 2 di SMAN 2 Jember, maka dapat disimpulkan beberapa hal sebagai berikut.

1. Hasil validasi yang dilakukan pada isi/materi dan model pembelajaran pada tahap I belum layak untuk diujicobakan dan ada beberapa revisi kemudian pada tahap ke II dapat dikategorikan layak untuk di ujicobakan tetapi ada beberapa hal yang harus direvisi kembali, pada tahap validasi ke III dikategorikan layak untuk diujicobakan tanpa revisi.

2. Hasil penelitian mengenai kemenarikan model blended learning ditunjukkan dengan hasil ratarata angket respon peserta didik. Hasil tersebut tergolong dalam rentang nilai 81\%-100\%, dengan kategori sangat menarik. Sehingga dapat disimpulkan bahawa model blended learning sangat menarik diterapkan dalam proses pembelajaran.

3. Hasil penelitian mengenai keefektifan model blended learning ditunjukkan dengan hasil belajar peserta didik (pretest dan postest). Hasil tersebut dianalisis menggunakan uji beda sample 
paired $\mathrm{t}$ test, dan hasilnya menunjukkan bahwa nilai postest 80 nilai pretest 72 sehingga dapat disimpulkan bahwa model blended learning efektif dalam mencapai tujuan pembelajaran.

Hasil penelitian mengenai keefisienan model blended learning ditunjukkan dengan hasil perbedaan waktu antara model klasikal dan model blended learning diketahui dari durasi penggunaan waktu yang semakin singkat dan peserta didik menunjukkan paham terhdap materi yang disampaikan. Sehingga dapat disimpulkan bahawa model blended learning efisien dalam proses pembelajaran

Saran pengembangan model blended learning menurut peneliti ada beberapa poin, yaitu:

a. Perluasan subjek ujicoba yang diteleiti, tidak hanya sebatas satu kelas saja.

b. Perluasan KD yang digunakan model blended learning, tidak hanya sebatas KD sistem dan alat pembayaran, namun perlu diperhatikan kebutuhan dengan melihat karakteristik peserta didik dan guru.

c. Penggunaan e-learning online yang lain tidak hanya dengan quipper shcool tetapi bisa dengan e-learning yang lain seperti edmodo.

\section{DAFTAR PUSTAKA}

Arikunto, Suharsimi. 2010. Evalusasi Program Pendidikan: Pedoman teoritis praktis bagi mahasiswa dan praktisi pendidikan. Jakarta: Bumi aksara.

Aunurrahman. 2014. Belajar dan Pembelajaran. Bandung:Alfabeta.

Husamah. 2014. Pembelajaran Bauran (Blended learning). Jakarta: Prestasi Pustaka.

Rohani, Ahmad.2010. Pengolahan Pengajaran. Bandung: Rineka Cipta.

Tegeh, M., N. Jampel. Pudjawan. 2014. Model Penelitian Pengembangan. Yogyakarta: Graha Ilmu. 